https://doi.org/10.11646/palaeoentomology.4.3.1

http://zoobank.org/urn:1sid:zoobank.org:pub:726B4CE1-2AD7-485E-BA56-EE0E99DF38B5

\title{
International Palaeoentomological Society Statement on unethical practices in describing new taxa
}

\author{
INTERNATIONAL PALAEOENTOMOLOGICAL SOCIETY \\ International Palaeoentomological Society, c/o Museum national d'Histoire naturelle, CP. 5045 rue Buffon, F-75231 Paris cedex 05, \\ France
}

Taxonomy or biological systematics is the basic scientific discipline of biology, postulating hypotheses of identity and relationships, on which all other natural sciences dealing with organisms relies. Taxonomy as the scientific discipline that explores, discovers, interprets, represents, names, and organizes organic beings (Ebach et al., 2011), is one of the oldest biological disciplines. Taxonomy is a scientific discipline that has provided the universal naming and classification system of biodiversity for centuries and continues effectively to accommodate new knowledge (Thomson et al., 2018). However, taxonomic impediment, decrease in the number of taxonomists, lack of appreciation for this area of research is not only the problem for studies on Recent organisms and their diversity (Wägele et al., 2011; Britz et al., 2020; Vinarski, 2020; Raposo et al., 2021), but it is affecting seriously also research and studies on fossils, their taxonomy and their palaeodiversity.

Dissemination of results is one of the critical steps in the practice of science, and today's scientists do this in many forms: through presentations at conferences, invited lectures, and most importantly through publication (Knapp \& Wright, 2010). However, current 'publish or perish' cult (Clapham, 2005; Rawat \& Meena, 2014; Grimes et al., 2018) promotes inaccuracy in science, strongly affecting taxonomy, taxonomists and taxonomic activities.

The Scientific Committee of the International Palaeoentomological Society must not remain indifferent to situations that threaten the honesty and transparency of science practiced by palaeoentomologists. The IPS and Editorial board of our journal Palaeoentomology becomes concerned about acts of violating generally accepted principles of ethics in science. The Editorial Office of Palaeoentomology encountered recently an ethical problem with papers describing new Tingidae taxa. The paper authored by Heiss E. \& Golub V. was received on $27^{\text {th }}$ February, 2021 and got its final acceptance on $6^{\text {th }}$ April, 2021. Meanwhile, another submission by Souma J., Yamamato S. \& Takahashi Y. was presented to the Palaeoentomology editorial submission system on $25^{\text {th }}$
March, 2021. The handling Editor found that the taxa proposed by the Japanese team is corresponding to the same taxa presented by Heiss E. \& Golub V. in their contribution. The Editorial Office contacted all the corresponding authors and proposed a collaboration between the teams. He stated to the Japanese corresponding author Yamamato as well that the paper of Heiss is already accepted after review (minor revision) and normally it will be published by the end of April. Japanese authors decided to withdraw the paper $\left(27^{\text {th }}\right.$ March, 2021) and refused collaboration, while Heiss expressed a very positive attitude and was ready to any collaboration on this issue. The situation came, when Japanese authors submitted their paper in a rushed way to MDPI journal Taxonomy on $2^{\text {nd }}$ April, 2021, while they were already awarded of the acceptance of Heiss paper and refused the collaboration and withdrew their paper from Palaeoentomology. The Japanese paper got accepted on $21^{\text {st }}$ April, 2021 and published on $24^{\text {th }}$ April, 2021 in MDPI's Taxonomy (Souma et al., 2021), few days before issue of Palaeoentomology with Heiss \& Golub (2021a) paper was published. This action led to unnecessary synonymy, published in the current issue of Palaeoentomology (Heiss \& Golub, 2021b). The situation was presented to IPS managing bodies and Japanese team action was found as breaching the Code of Ethics of the International Code of Zoological Nomenclature (ICZN, 1999).

Naming species forms the foundation of biologybut a zealous "pursuit for names only" can expose the dangers to the taxonomic system and its rules. As such behaviour increases; IPS and its Scientific Committee feel responsible to point out the ethical issues involved with descriptions of taxa. The situations that have taken place recently, concern the unethical behaviour of palaeoentomologists who, short-sightedly, place their own personal or scientific (career) interests in describing new taxa above the common interest that underpins the basic tenets of international science.

Therefore, we would like to remind that the Code 
of the Zoological Nomenclature (ICZN, 1999), has Appendices, which guide the ethical dimension of taxonomic activity. Palaeoentomologists are part of taxonomic community, and as such, are bound by the rules of the Code, as well as its appendices. As the IPS journal Palaeoentomology, requires its Authors to comply with the rules, recommendations, and appendices of the Code, we strongly recommend these should also be applied by Authors presenting their papers to other journals dealing with taxonomy and taxonomic descriptions.

To help elucidate this point, we recall the basic ethical principles for establishing new taxa and hope that non-ethical behaviour will no longer take place among taxonomists, and especially within palaeoentomological community. Appendix A of the International Code of Zoological Nomenclature, $4^{\text {th }}$ edition, being in force since 1 January 2000 (ICZN, 1999) includes points on ethics and transparency when describing (establishing) new taxa. Section 2 of ICZN Code Appendix A clearly states that "A zoologist should not publish a new name if he or she has reason to believe that another person has already recognized the same taxon and intends to establish a name for it". If the researcher receives information that the taxon is already the subject of the description, “... should communicate with the other person (or their representatives) and only feel free to establish a new name if that person has failed to do so in a reasonable period (not less than a year)".

In addition, the Code of Ethics also imposes obligations on journal editors. In section 6 of Appendix A (ICZN, 1999) it says that "Editors and others responsible for the publication of zoological papers should avoid publishing any material which appears to them to contain a breach of the above principles".

Recent examples of breaches of the Code of Ethics give rise to serious concern from IPS Scientific Committee and palaeoentomological community. As scientists, taxonomists, we are obliged to abide by the rules of the Code, we cannot support activities inconsistent with its rules and recommendations, and we cannot remain indifferent to the manifestations of taxonomic vandalism and poor taxonomic practices (Borrell, 2007; Wüster et al., 2021; Zamani et al., 2021). Such practices can disrupt funding bodies, institutional authorities and administrations, and negatively affect public perception of taxonomy and palaeoentomology.

\section{References}

Borrell, B. (2007) The big name hunters. Nature, 446, 253-255. https://doi.org/10.1038/446253a
Britz, R., Hundsdörfer, A. \& Fritz, U. (2020) Funding, training, permits - the three big challenges of taxonomy. Megataxa, 1 (1), 49-52. https://doi.org/10.11646/megataxa.1.1.10

Clapham, P. (2005) Publish or perish. BioScience, 55 (5), 390 391.

https://doi.org/10.1641/0006-3568(2005)055[0390:POP]2.0.CO;2

Ebach, M.C., Valdecasas, A.G. \& Wheeler, Q.D. (2011) Impediments to taxonomy and users of taxonomy: accessibility and impact evaluation. Cladistics, 27, 550557. https://doi.org/10.1111/j.1096-0031.2011.00348.x

Grimes, D.R., Bauch, C.T. \& Ioannidis, J.P.A. (2018) Modelling science trustworthiness under publish or perish pressure. Royal Society open science, 5, 1715. https://doi.org/10.1098/rsos.171511

Heiss, E. \& Golub, V. (2021a) A new genus and species of Tingidae from Cretaceous Burmese amber (Hemiptera, Heteroptera). Palaeoentomology, 4 (2), 137-140.

https://doi.org/10.11646/palaeoentomology.4.2.2

Heiss, E. \& Golub, V. (2021b) New synonymy in Burmese amber Tingidae (Hemiptera, Heteroptera). Palaeoentomology, 4 (3), 202.

https://doi.org/10.11646/palaeoentomology.4.3.2

ICZN (1999) International Code of Zoological Nomenclature. Fourth edition. Available online at: [https://www.iczn.org/ the-code/the-international-code-of-zoological-nomenclature/ the-code-online/]

Knapp, S. \& Wright, D. (2010) e-Publish or Perish? In: Polaszek, A. (Ed.), Systema Naturae 250. The Linnaean Ark. CRC Group, Taylor and Francis LLC, Boca Raton, Florida, pp. 83-93. https://doi.org/10.1080/14772000.2020.1829157

Raposo, M.A., Kirwan, G.M., Calijorne Lourenço, A.C., Sobral, G., Bockmann, F.A. \& Stopiglia, R. (2020) On the notions of taxonomic 'impediment', 'gap', 'inflation' and 'anarchy', and their effects on the field of conservation. Systematics and Biodiversity, 19 (3), 296-311. https://doi.org/10.1080/14772000.2020.1829157

Rawat, S. \& Meena, S. (2014) Publish or perish: Where are we heading? Journal of research in medical sciences: the official journal of Isfahan University of Medical Sciences, 19 (2), 87-89.

https://doi.org/10.3390/taxonomy1020007

Souma, J., Yamamoto, S. \& Takahashi, Y. (2021) Discovery of the smallest lace bug from mid-Cretaceous of northern Myanmar supports the hypothesis of a miniaturization phenomenon of insects in Kachin amber (Hemiptera: Heteroptera: Tingidae). Taxonomy, 1 (2), 60-68. https://doi.org/10.1371/journal.pbio.2005075

Thomson, S.A., Pyle, R.L., Ahyong, S.T., Alonso-Zarazaga, M., Ammirati, J., Araya, J.F., Ascher, J.S., Audisio, T.L., Azevedo-Santos, V.M., Bailly, N., Baker, W.J., Balke, M., Barclay, M.V.L., Barrett, R.L., Benine, R.C., Bickerstaff, J.R.M., Bouchard,P., Bour, R., Bourgoin, T., Boyko, C.B., 
Breure, A.S.H., Brothers, D.J., Byng, J.W., Campbell, D., Ceríaco, L.M.P., Cernák, I., Cerretti, P., Chang, C.-H., Cho, S., Copus, J.M., Costello, M.J., Cseh, A., Csuzdi, C., Culham, A., D'Elía, G., d'Udekem d'Acoz, C., Daneliya, M.E., Dekker, R., Dickinson, E.C., Dickinson, T.A., van Dijk, P.P., Dijkstra, K.-D.B., Dima, B., Dmitriev, D.A., Duistermaat, L., Dumbacher, J.P., Eiserhardt, W.L., Ekrem, T., Evenhuis, N.L., Faille, A., Fernández-Triana, J.L., Fiesler, E., Fishbein, M., Fordham, B.G., Freitas, A.V.L., Friol, N.R., Fritz, U., Frøslev, T., Funk, V.A., Gaimari, S.D., Garbino, G.S.T., Garraffoni, A.R.S., Geml, J., Gill, A.C., Gray, A., Grazziotin, F.G., Greenslade, P., Gutiérrez, E.E., Harvey, M.S., Hazevoet, C.J., He, K., He, X., Helfer, S., Helgen, K.M., van Heteren, A.H., Garcia, F.H., Holstein, N., Horváth, M.K., Hovenkamp, P.H., Hwang, W.S., Hyvönen, J. Islam, M.B., Iverson, J.B., Ivie, M.A., Jaafar, Z., Jackson, M.D., Jayat, J.P., Johnson, N.F., Kaiser, H., Klitgård, B.B., Knapp, D.G., Kojima, J., Kõljalg, U., Kontschán, J., Krell, F.-T., Krisai-Greilhuber, I., Kullander, S., Latella, L., Lattke, J.E., Lencioni, V., Lewis, G.P., Lhano, M.G., Lujan, N.K., Luksenburg, J.A., Mariaux, J., MarinhoFilho, J., Marshall, C.J., Mate, J.F., McDonough, M.M., Michel, E., Miranda, V.F.O., Mitroiu, M.-D., Molinari, J., Monks, S., Moore, A.J., Moratelli, R., Murányi, D., Nakano, T., Nikolaeva, S., Noyes, J., Ohl, M., Oleas, N.H., Orrell,T., Páll-Gergely, B., Pape, T., Papp, V., Parenti, L.R., Patterson, D., Pavlinov, I.Ya., Pine, R.H., Poczai, P., Prado, J., Prathapan, D., Rabeler, R.K., Randall, J.E., Rheindt, F.E., Rhodin, A.G.J., Rodríguez, S.M., Rogers, D.C., Roque, F.d.O., Rowe, K.C., Ruedas, L.A., Salazar-Bravo, J., Salvador, R.B., Sangster, G., Sarmiento, C.E., Schigel, D.S., Schmidt, S., Schueler, F.W.,
Segers, H., Snow, N., Souza-Dias, P.G.B., Stals, R., Stenroos, S., Stone, R.D., Sturm, C.F., Štys, P., Teta, P., Thomas, D.C., Timm, R.M., Tindall, B.J., Todd, J.A., Triebel, D., Valdecasas, A.G., Vizzini, A., Vorontsova, M.S., de Vos, J.M., Wagner, P., Watling, L., Weakley, A., Welter-Schultes, F., Whitmore, D., Wilding, N., Will, K., Williams, J., Wilson, K., Winston, J.E., Wüster, W., Yanega, D., Yeates, D.K., Zaher, H., Zhang, G., Zhang, Z.Q. \& Zhou, H.Z. (2018) Taxonomy based on science is necessary for global conservation. PLoS Biology, 16 (3), e2005075.

https://doi.org/10.1371/journal.pbio.2005075

Vinarski, M.V. (2020) Roots of the taxonomic impediment: is the "integrativeness" a remedy? Integrative Zoology, 15 (1), $2-15$.

https://doi.org/10.1111/1749-4877.12393

Wägele, H., Klussmann-Kolb, A., Kuhlmann, M., Haszprunar, G., Lindberg, D., Koch, A. \& Wägele, J.W. (2011) The taxonomist — an endangered race. A practical proposal for its survival. Frontiers in Zoology, 8 (25), 1-7. https://doi.org/10.1093/biolinnean/blab009

Wüster, W., Thomson, S.A., O'Shea, M. \& Kaiser, H. (2021) Confronting taxonomic vandalism in biology: conscientious community self-organization can preserve nomenclatural stability. Biological Journal of the Linnean Society, blab009. https://doi.org/10.1093/biolinnean/blab009

Zamani, A., Vahtera, V., Sääksjärvi, I.E. \& Scherz, M.D. (2021) The omission of critical data in the pursuit of 'revolutionary' methods to accelerate the description of species. Systematic Entomology, 46, 1-4.

https://doi.org/10.1111/syen.12444 